\title{
Anomalous Left Coronary Artery from Pulmonary Artery: An Important Cause of Ischemic Mitral Regurgitation in Children
}

\author{
Muhammad Kamran Younis Memon ${ }^{1}$, Muneer Amanullah ${ }^{2}$, Mehnaz Atiq ${ }^{3}$ \\ 1. Pediatrics and Child Health, Liaquat National Hospital and Medical College, Karachi, PAK 2. Pediatric \\ Cardiac Surgery, National Institute of Cardiovascular Disease, Karachi, PAK 3. Pediatric Cardiology, \\ Liaquat National Hospital, Karachi, PAK
}

Corresponding author: Mehnaz Atiq, mehnaz.atiq@lnh.edu.pk

\section{Abstract}

Introduction: Anomalous left coronary artery from the pulmonary artery (ALCAPA) is a rare congenital anomaly. The usual presentation in infancy is inconsolable crying or congestive cardiac failure, both due to myocardial ischemia. Survivors after infancy have improved left ventricular function but continue to have mitral regurgitation due to papillary muscle ischemia. The present study emphasizes the importance of unexplained mitral regurgitation as a clue to the diagnosis.

Patients and Methods: Patients with the diagnosis of ALCAPA operated between June 2017 and May 2018 were enrolled. Their ages at diagnosis, electrocardiography, and echocardiography findings were noted. A selective angiogram of the right coronary artery was done in all. Results of surgical reimplantation were analyzed. Postoperative data were collected, including ventricular function and mitral regurgitation.

Results: Six patients were included. Clinical signs of cardiac failure were present in two patients, and a systolic murmur was heard in all. The mean left ventricular ejection fraction was $52 \pm 12 \%$. Mitral regurgitation was present in all of the patients. The right coronary artery was dilated (Z score $>2.5$ ) in all except one. Selective right coronary angiogram and cardiac computerized tomography angiogram (CTA) were performed in all. Coronary reimplantation was successfully done. Follow-up echocardiography showed improved left ventricular ejection fraction and degree of mitral regurgitation in all patients.

Conclusion: ALCAPA is an uncommon congenital anomaly, the diagnosis of which can be missed, particularly in late presenters. Unexplained mitral regurgitation should always raise the suspicion of this anomaly. Surgical intervention has excellent results with an improvement of left ventricular function and mitral regurgitation.

Received 03/01/2019

Review began 03/06/2019

Review ended 04/09/2019

Published 04/12/2019

CC Copyright 2019

Memon et al. This is an open access article distributed under the terms of the Creative Commons Attribution License CC-BY 3.0., which permits unrestricted use, distribution, and reproduction in any medium, provided the original author and source are credited.
Categories: Cardiology, Pediatrics

Keywords: mitral regurgitation, dilated cardiomyopathy, anomalous coronary artery from pulmonary artery (alcapa)

\section{Introduction}

Anomalous left coronary artery from the pulmonary artery (ALCAPA) is a rare congenital anomaly occurring in 1:300,000 live births with a male preponderance, the ratio being 2:1 [1]. It is also called Bland-White-Garland syndrome, after clinicians who described the full spectrum 
of the disorder in 1933 and showed that the combined effects of the absence of normal coronary flow and a coronary steal produce profound myocardial ischemia leading to left ventricular dysfunction and mitral regurgitation [2]. Untreated, this anomaly carries a 90\% mortality in the first year of life [3-4]. The usual presentation is in infancy with angina pain causing inconsolable crying or congestive cardiac failure, both due to myocardial ischemia. A subset may present after infancy with mitral regurgitation with or without other features of myocardial ischemia. Failure to diagnose and operate early leads to an overall grim outlook. We present our experience of an ALCAPA in infants and children presenting with mitral regurgitation as the predominant clinical and echocardiography feature, which improved postoperatively.

\section{Materials And Methods}

All consecutive patients with the diagnosis of an anomalous left coronary artery from pulmonary artery presenting from June 2017 to May 2018 were included. Clinical presentation was noted. The presence of congestive cardiac failure, inconsolable crying in infancy, and failure to thrive were noted. Clinical examination for poor growth, signs of congestive heart failure, and the presence of a murmur were sought. Electrocardiogram, echocardiogram, and selective right coronary angiogram were done in all patients. All patients had a computerized tomographic angiogram (CTA) done to evaluate the distance of the anomalous left coronary artery from the aortic root.

Surgical intervention included reimplantation of the left coronary artery to the aorta. Mitral annuloplasty was additionally performed in a 13-year-old with severe mitral regurgitation. All patients were discharged from the hospital.

\section{Results}

Six patients with the diagnosis of an ALCAPA were included. None of the patients had a history of inconsolable crying episodes in early infancy. Clinical signs of cardiac failure were present in two patients, and an apical systolic murmur was heard in all patients. Preoperative and postoperative data are shown in Tables 1-2, respectively. 


\section{Cureus}

\begin{tabular}{|c|c|c|c|c|c|}
\hline 焉 & $\begin{array}{l}\text { Age at } \\
\text { Diagnosis } \\
\text { (yrs), } \\
\text { Gender }\end{array}$ & $\begin{array}{l}\text { Age at } \\
\text { Surgery } \\
\text { (yrs) }\end{array}$ & Echocardiography Findings & $\begin{array}{l}\text { Preoperative } \\
\text { ECG }\end{array}$ & $\begin{array}{l}\text { Selective Coronary Angiography } \\
\text { Findings }\end{array}$ \\
\hline 1 & $8 \mathrm{~F}$ & 8 & $\begin{array}{l}\text { RCA z score }+3 \text {, mild LV systolic } \\
\text { dysfunction, mild to moderate MR, } \\
\text { echogenic mitral valve papillary } \\
\text { muscles, trace TR, color flow Doppler } \\
\text { signals in RV wall, and IVS }\end{array}$ & $\begin{array}{l}\text { Q waves in I, } \\
\text { II }\end{array}$ & $\begin{array}{l}\text { Dilated RCA, well-developed } \\
\text { collateral circulation, retrograde } \\
\text { filling the LCA, significant } \\
\text { opacification of PA }\end{array}$ \\
\hline 2 & $15 \mathrm{M}$ & 15 & $\begin{array}{l}\text { RCA z score }+3.5 \text {, moderate MR, low } \\
\text { normal LV systolic function, color flow } \\
\text { Doppler signals in RV wall, and IVS }\end{array}$ & Normal & $\begin{array}{l}\text { Dilated RCA, well-developed } \\
\text { collateral circulation, retrograde } \\
\text { filling of LCA, opacification of PA. } \\
\text { LAD artery arising from the left } \\
\text { coronary sinus and connecting to } \\
\text { PA like a fistula }\end{array}$ \\
\hline 3 & $9 \mathrm{M}$ & 10 & $\begin{array}{l}\text { RCA z score }+5 \text {, normal LV function, } \\
\text { moderate MR, trace TR, color flow } \\
\text { Doppler signals in RV wall, and IVS }\end{array}$ & Normal & $\begin{array}{l}\text { Dilated RCA, well-developed } \\
\text { collateral circulation, retrograde } \\
\text { filling the LCA, and significant } \\
\text { opacification of PA }\end{array}$ \\
\hline 4 & $6 \mathrm{~F}$ & 6 & $\begin{array}{l}\text { RCA z score }+4 \text {, Normal LV systolic } \\
\text { function and mild to moderate MR, trace } \\
\text { TR, color flow Doppler signals in RV } \\
\text { wall, and IVS }\end{array}$ & $\begin{array}{l}\text { Q waves in I, } \\
\text { II, V4, V5 }\end{array}$ & $\begin{array}{l}\text { Dilated RCA, well-developed } \\
\text { collateral circulation, retrograde } \\
\text { filling the LCA, and significant } \\
\text { opacification of PA }\end{array}$ \\
\hline 5 & $13 \mathrm{~F}$ & 13 & $\begin{array}{l}\text { RCA z score }+5.5 \text {, low normal systolic } \\
\text { LV function, severe MR, color flow } \\
\text { Doppler signals in RV wall and IVS }\end{array}$ & $\begin{array}{l}\mathrm{LVH}, \text { no Q } \\
\text { waves }\end{array}$ & $\begin{array}{l}\text { Dilated RCA, well-developed } \\
\text { collateral circulation, retrograde } \\
\text { filling the LCA, significant } \\
\text { opacification of PA }\end{array}$ \\
\hline 6 & $0.5 \mathrm{~F}$ & 1.5 & $\begin{array}{l}\text { RCA z score }+1 \text {, severe LV dysfunction } \\
\text { and severe MR, moderate TR, color } \\
\text { flow Doppler signals in RV wall and IVS }\end{array}$ & $\begin{array}{l}\text { Prolonged } \\
\text { QTc, no Q } \\
\text { waves }\end{array}$ & $\begin{array}{l}\text { Mildly dilated RCA, inadequately } \\
\text { developed collateral circulation, } \\
\text { retrograde filling the LCA, mild } \\
\text { opacification of PA }\end{array}$ \\
\hline
\end{tabular}

\section{TABLE 1: Preoperative Patient Data}

IVS: interventricular septum; LAD: left anterior descending; LCA: left coronary artery; LV: left ventricle; MR: mitral regurgitation; PA: pulmonary artery; QTC: corrected QT interval; RCA: right coronary artery; RV: right ventricle; TR: tricuspid regurgitation 


\section{Cureus}

\begin{tabular}{|c|c|c|c|c|c|c|c|}
\hline $\begin{array}{l}\text { S } \\
\#\end{array}$ & $\begin{array}{l}\text { CPB } \\
\text { time } \\
\text { (min) }\end{array}$ & $\begin{array}{l}\text { ACC } \\
\text { time } \\
(\min )\end{array}$ & $\begin{array}{l}\text { lonotropic } \\
\text { score }\end{array}$ & $\begin{array}{l}\text { Postoperative } \\
\text { arrhythmia }\end{array}$ & $\begin{array}{l}\text { Duration } \\
\text { of } \\
\text { intubation } \\
\text { (days) }\end{array}$ & $\begin{array}{l}\text { Duration } \\
\text { of hospital } \\
\text { stay } \\
\text { (days) }\end{array}$ & $\begin{array}{l}\text { Postoperative echocardiography } \\
\text { findings one-month postoperative } \\
\text { follow-up }\end{array}$ \\
\hline 1 & 75 & 50 & 0 & none & 1 & 5 & $\begin{array}{l}\text { Normal LV systolic function, no MR, normal } \\
\text { appearance of the reimplanted coronary } \\
\text { artery }\end{array}$ \\
\hline 2 & 150 & 80 & 5 & none & 1 & 5 & Normal LV systolic function, mild MR \\
\hline 3 & 80 & 40 & 0 & none & 1 & 6 & $\begin{array}{l}\text { Normal LV function, mild MR, reimplanted } \\
\text { coronary artery mildly dilated, Z score }+2.5\end{array}$ \\
\hline 4 & 90 & 34 & 8 & none & 1 & 6 & $\begin{array}{l}\text { Normal LV systolic function, mild MR, } \\
\text { normal appearance of the reimplanted } \\
\text { coronary artery }\end{array}$ \\
\hline 5 & 135 & 115 & 0 & none & 1 & 6 & $\begin{array}{l}\text { Normal LV systolic function, moderate MR, } \\
\text { normal appearance of the reimplanted } \\
\text { coronary artery }\end{array}$ \\
\hline 6 & 130 & 95 & 5 & $\begin{array}{l}\text { of VT } \\
\text { ofsode }\end{array}$ & 8 & 14 & $\begin{array}{l}\text { Severe LV systolic dysfunction (but } \\
\text { improved), moderate MR, normal } \\
\text { appearance of the reimplanted coronary } \\
\text { artery }\end{array}$ \\
\hline
\end{tabular}

\section{TABLE 2: Operative and Postoperative Data}

ACC: aorta cross-clamp; CPB: cardiopulmonary bypass; LV: left ventricle; MR: mitral regurgitation; VT: ventricular tachycardia

Two patients had $\mathrm{Q}$ waves in the electrocardiogram, two had non-specific repolarization abnormalities, and in the remaining two, it was normal. The echocardiogram showed severe left ventricular dysfunction in only one patient and three had a low normal systolic function, whereas two had normal left ventricular function. The mean ejection fraction was $52 \pm 12 \%$. Mitral regurgitation of varying degrees was present in all patients. All patients also had color flow Doppler signals in the right ventricular wall and interventricular septum (IVS), indicating dilated collateral connections between the right and left coronary arteries. The right coronary artery was dilated on echocardiography in the short axis view (Z score $>2.5$ ) in all patients, except in Patient \#6 who had poorly developed collaterals and severe left ventricular dysfunction. Selective right coronary angiogram was performed on all patients, and it demonstrated dilated right coronary artery with collaterals filling the left coronary system and retrograde opacification of the main pulmonary artery (Figure 1). CTA confirmed that the distance of the left coronary artery from the aortic root was close enough for reimplantation. 


\section{Cureus}

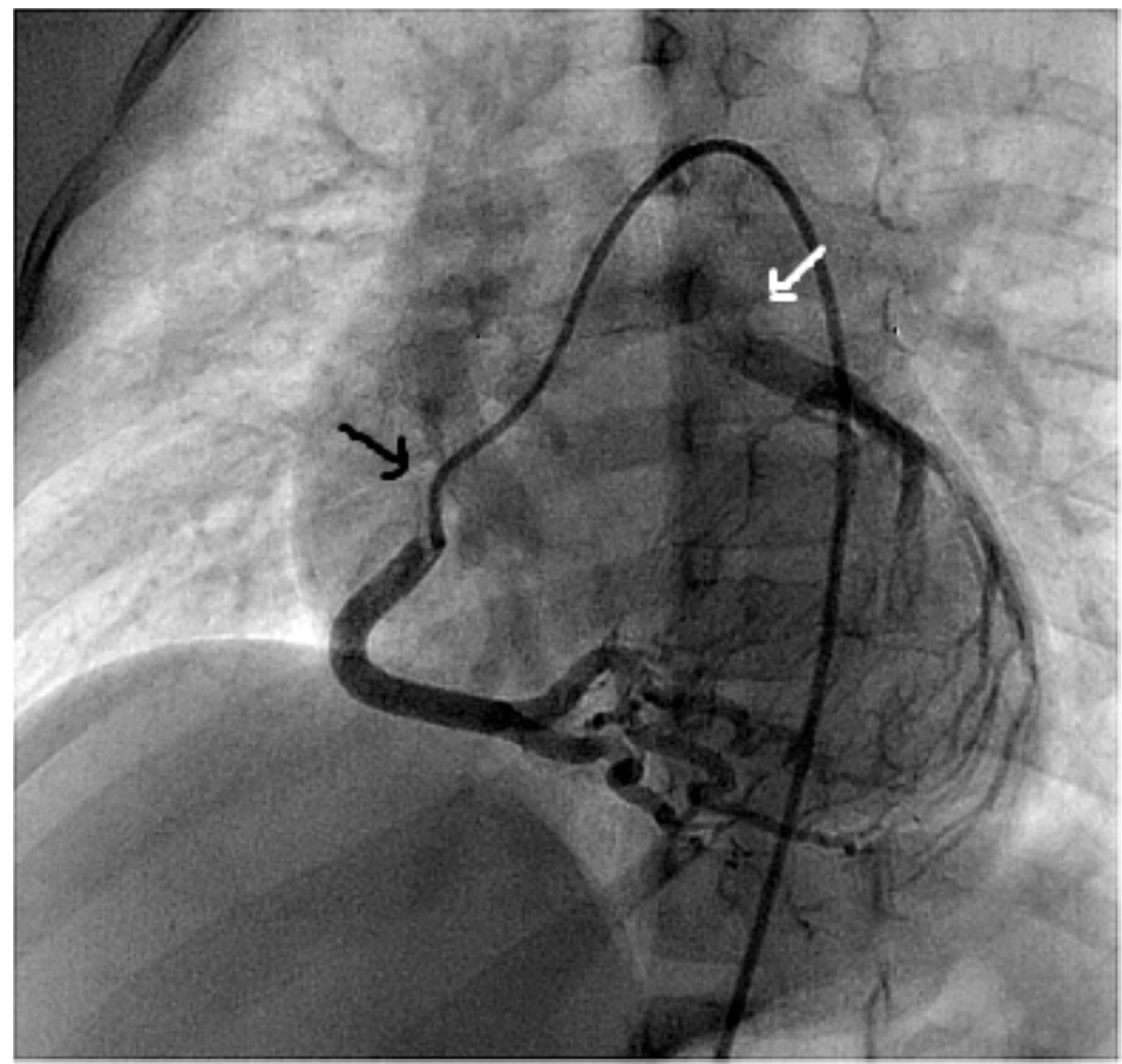

FIGURE 1: Selective right coronary angiogram (black arrow) in Patient \#1, showing retrograde filling of the left coronary artery which opens into the pulmonary artery (white arrow)

All patients underwent coronary reimplantation. The mean cardiopulmonary bypass time was $103 \pm 22$ minutes, and aorta cross-clamp time $71 \pm 10$ minutes. Mitral valve annuloplasty was performed in one child. Postoperatively mean inotropic score was $2.9 \pm 0.3$, and none had low cardiac output syndrome. All patients were discharged on beta blockers, angiotensinconverting enzyme inhibitors, diuretics, and aspirin. Follow-up echocardiogram performed one month later showed improved left ventricular ejection fraction and the degree of mitral regurgitation in all patients.

\section{Discussion}

ALCAPA causes insidious myocardial ischemia, leading to left ventricular systolic dysfunction. Three embryological theories have been put forth to explain this anomaly: the first proposes an abnormal disposition of the aortopulmonary septum; the second one suggests persistence of the left coronary buds on the pulmonary artery and involution of the aortic buds permitting anomalous development of that coronary from the wrong artery; the third one relates to a septation defect of the conotruncus tube [4-5]. The anomaly rarely involves the right coronary artery, left anterior descending artery, or both coronary arteries, the latter being incompatible with life [6]. Although reported to be fatal in infancy, children can survive past infancy into 
teenage and adulthood without symptoms. In them, an ALCAPA anomaly is an important cause of serious arrhythmias and sudden cardiac death [7].

The pathophysiology of the disorder relates to the pressure difference between the systemic and pulmonary arteries and the development of adequate collateral coronary circulation [8]. Four hemodynamic phases have been described. The first stage is in neonates with elevated pulmonary artery pressures supplying the left coronary artery with no myocardial ischemia. The second stage is when the pulmonary arterial pressure and vascular resistance fall and a reversal of flow from the left coronary artery occurs, resulting in a steal phenomenon. If collaterals from the right coronary artery are inadequate, hypoperfusion and myocardial ischemia develop. The third stage is the development of adequate collaterals connections between the two coronary circulations, resulting in better myocardial perfusion and improved myocardial function. The fourth stage is of normal pulmonary arterial pressure and vascular resistance with the left coronary circulation supplied by the right coronary artery and a left-toright shunt ensues into the pulmonary artery. This causes subclinical myocardial ischemia leading to mitral valve regurgitation and sudden cardiac death due to arrhythmia [5-6]. The first two stages explain the pediatric type and the last two are found in the adult type of presentations. The echocardiographic clue to coronary artery collateral connections is the color flow Doppler signals in the right ventricular myocardium and interventricular septum.

Mitral regurgitation, as a disease entity, can be primarily due to a diseased mitral valve or its apparatus or secondary due to a diseased left ventricle [9]. The latter is due to pathological remodeling of the left ventricle due to either cardiomyopathy or coronary artery disease. Mitral regurgitation in the ALCAPA is due to 1) annular dilatation of the mitral valve secondary to ischemic left ventricular enlargement and dysfunction or 2) ischemic papillary muscle dysfunction, or both [10]. The former occurs in infancy and the latter in older children and adults. Understanding the mechanism is important for surgical management of the mitral valve.

Surgical intervention included coronary reimplantation in all of our cases. The patient with an accessory left anterior descending artery coronary connecting to the pulmonary artery as a fistula was ligated. Very few cases of additional coronary artery abnormalities have been reported previously [11]. After revascularization, the left ventricular function and size improved in five patients within one month. Mitral regurgitation improved in all patients, which may also have been due to improved perfusion of the mitral valve apparatus, as has also reported previously [12]. It is generally recommended not to address the mitral valve during the initial surgery as there is a high probability of mitral regurgitation improving with postoperative ventricular remodeling and reperfusion [10]. We performed an annuloplasty in the 13-year-old girl (Patient \#5) due to severe mitral regurgitation.

\section{Conclusions}

ALCAPA is an uncommon congenital anomaly. Diagnosis can be missed, particularly in late presenters, due to normalization of the left ventricular function. However, mitral regurgitation persists in this subset. Electrocardiographic abnormalities may not always be present in late presenters. Dilated cardiomyopathy with secondary mitral regurgitation is the common presentation in infancy. Surgical intervention has excellent results at all ages with improvement in left ventricular function and mitral regurgitation. The present study emphasizes the importance of unexplained mitral regurgitation as a clue to the diagnosis and its improvement after surgery. It is also imperative that a long-term follow-up of these patients is planned with an electrocardiogram and echocardiogram to look for arrhythmia, as well as left ventricular function and mitral regurgitation, respectively. 


\section{Additional Information}

\section{Disclosures}

Human subjects: Consent was obtained by all participants in this study. Aga Khan University Ethical Review Committee issued approval --. The study was approved for clinical report by the committee members. No objection was raised on the design and clinical content. Animal subjects: All authors have confirmed that this study did not involve animal subjects or tissue. Conflicts of interest: In compliance with the ICMJE uniform disclosure form, all authors declare the following: Payment/services info: All authors have declared that no financial support was received from any organization for the submitted work. Financial relationships: All authors have declared that they have no financial relationships at present or within the previous three years with any organizations that might have an interest in the submitted work. Other relationships: All authors have declared that there are no other relationships or activities that could appear to have influenced the submitted work.

\section{References}

1. Lange R, Vogt M, Hörer J, et al.: Long-term results of repair of anomalous origin of the left coronary artery from the pulmonary artery. Ann Thorac Surg. 2007, 83:1463-71.

10.1016/j.athoracsur.2006.11.005

2. Brown JW, Ruzmetov M, Parent JJ, Rodefeld MD, Turrentine MW: Does the degree of preoperative mitral regurgitation predict survival or the need for mitral valve repair or replacement in patients with anomalous origin of the left coronary artery from the pulmonary artery?. J Thorac Cardiovasc Surg. 2008, 136:743-48. 10.1016/j.jtcvs.2007.12.065

3. Alexi-Meskishvili V, Nasseri BA, Nordmeyer S, et al.: Repair of anomalous origin of the left coronary artery from the pulmonary artery in infants and children. J Thorac Cardiovasc Surg. 2011, 142:868-74. 10.1016/j.jtcvs.2011.04.006

4. Moeinipour A, Teshnisi MA, Shahri HMM, Zirak N, Hasanzadeh R, Hoseinikhah H, Bahreini A: Anomalous origin of the left coronary artery from the pulmonary artery (ALCAPA): a case series and brief review. Int J Pediatr. 2016, 4:1397-405.

5. Villa ADM, Sammut E, Nair A, Rajani R, Bonamini R, Chiribiri A: Coronary artery anomalies overview: the normal and the abnormal. World J Radiol. 2016, 8:537-55. 10.4329/wjr.v8.i6.537

6. Dilawar M, Ahmad Z: Anomalous left coronary artery from pulmonary artery: Case series and brief review. Open J Pediatr. 2012, 2:77-81. 10.4236/ojped.2012.21013

7. Kudumula V, Mehta C, Stumper O, et al.: Twenty year outcome of anomalous origin of left coronary artery from pulmonary artery: management of mitral regurgitation. Ann Thorac Surg. 2014, 97:938-44. 10.1016/j.athoracsur.2013.11.042

8. Cochrane AD, Coleman DM, Davis AM, et al.: Excellent long-term functional outcome after an operation for anomalous left coronary artery from the pulmonary artery. J Thorac Cardiovasc Surg. 1999, 117:332-42. 10.1016/S0022-5223(99)70431-9

9. Varma PK, Krishna N, Jose RL, Madkaiker AN: Ischemic mitral regurgitation. Ann Card Anaesth. 2017, 20:432-39. 10.4103/aca.ACA_58_17

10. Ben Ali W, Metton O, Roubertie F, Pouard P, Sidi D, Raisky O, Vouhé PR: Anomalous origin of the left coronary artery from the pulmonary artery: late results with special attention to the mitral valve. Eur J Cardiothorac Surg. 2009, 36:244-49. 10.1016/j.ejcts.2009.03.014

11. Kasprzak JD, Al-Shaibi K, Ahmed W, Chamsi-Pasha H, Nosir YF: Anomalous origin of the left coronary artery: the rare coincidence of the left anterior descending coronary artery originating from the pulmonary artery and the circumflex coronary artery originating from the right sinus of valsalva. Rev Esp Cardiol. 2008, 61:1107-108. 10.1016/S18855857(09)60019-0

12. Ma K, Wang L, Hua Z, et al.: Outcomes of coronary transfer for anomalous origin of the left coronary artery from the pulmonary artery. Eur J Cardiothorac Surg. 2015, 47:659-64. 10.1093/ejcts/ezu274 